\title{
THE EFFECTS OF ADSORBENT MASS USING RED BRICK POWDER ON THE RESULTS OF BIOGAS PURIFICATION
}

\section{Slamet Wahyudi}

Brawijaya University, Faculty of Engineering, Department of Mechanical Engineering, Malang, Indonesia

\section{Firman Nurahmad Efendi}

Brawijaya University, Faculty of Engineering, Department of Mechanical Engineering, Malang, Indonesia

\begin{abstract}
Ahmat Faizal
Brawijaya University, Faculty of Engineering, Department of Mechanical Engineering, Malang, Indonesia
\end{abstract}

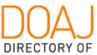

DIRECTORY OF
OPENACCES
JOURALS

Crossref

Key words: biogas purification, adsorbent of red brick powder, $2^{3}$ factorial design

Cite article:

Slamet, W., Firman, N. E., \& Ahmat, F. [2021]. The effects of adsorbent mass using red brick powder on the results of biogas purification. Journal of Applied Engineering Science, 19(1), 17 - 23. DOI:10.5937/jaes0-27726

Online aceess of full paper is available at: www.engineeringscience.rs/browse-issues
KOBSON

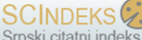

'81 Google 


\title{
THE EFFECTS OF ADSORBENT MASS USING RED BRICK POWDER ON THE RESULTS OF BIOGAS PURIFICATION
}

\author{
Slamet Wahyudi*, Firman Nurahmad Efendi, Ahmat Faizal \\ Brawijaya University, Faculty of Engineering, Department of Mechanical Engineering, Malang, Indonesia
}

Biogas is produced by the digestion of organic waste by anaerobic bacteria. However, the application of raw biogas is not effective because it consists of impurities such as carbon dioxide $\left(\mathrm{CO}_{2}\right)$, hydrogen sulfide $\left(\mathrm{H}_{2} \mathrm{~S}\right)$, water vapor $\left(\mathrm{H}_{2} \mathrm{O}\right)$, and other impurity gases. Physical Adsorption is the simplest method of immobilization of biomolecules such as $\mathrm{CO}_{2}$ which is attached to the surface through the weak bonds like van der Waals forces. One of the physical adsorption means to reduce $\mathrm{CO}_{2}$ levels in biogas is to use brick powder. Increasing of brick powder adsorbent mass caused the decrease of $\mathrm{CO}_{2}$ concentration in the biogas purification. Brick is a porous material containing $\mathrm{SiO}_{2}-$ $\mathrm{Al}_{2} \mathrm{O}_{3}$, so it has the ability to form Van Der Waals bonding forces with $\mathrm{CO}_{2}$. The goal of this research is to determine the efficiency of brick powder as a purification adsorbent to reduce of $\mathrm{CO}_{2}$ levels using the $2^{3}$ factorial design method. The application of 200 and 400 grams brick powder adsorbents, with the biogas flow rate of 1 and 2 liters/minute, was researched at intervals of 5 and 20 minutes, for the $\mathrm{CO}_{2}$ concentration data and heating values of biogas. Gas Chromatography (GC) was used to determine the concentration of adsorption gases, especially $\mathrm{CO}_{2}$ and $\mathrm{CH}_{4}$. The results showed that the biggest efficiency reduction in $\mathrm{CO}_{2}$ concentration is $59.28 \%$.

Key words: biogas purification, adsorbent of red brick powder, $2^{3}$ factorial design

\section{INTRODUCTION}

Renewable energy production is a big issue in the world. With different technologies, a lot of renewable energy can be obtained, such as: solar energy, wind energy, geothermal energy, and biomass energy [1]. Biomass is the main energy resource for biogas as a renewable energy, being mostly found in agricultural residues, livestock manure, and others [2]. Organic households, restaurants, parks, and wastes from industry [3], [4]. Biogas is produced from anaerobic bacterial digestion of degraded organic waste [5]. The composition of biogas consists of $35-75 \%$ methane, $25-65 \%$ carbon dioxide, $1-5 \%$ hydrogen, and tracer of water vapor, ammonia, and hydrogen sulfide. Poor biogas quality $\left(\mathrm{CH}_{4} / \mathrm{CO}_{2}<1\right)$ exacerbates damage to the atmosphere [6]. Purification techniques are used to clean and enhance biogas into biomethane which can replace natural gas [7].

Purification of biogas aims to improve its quality by separating non-methane gases, specifically carbon dioxide, which can reduce the heating value and the combustion efficiency [8]. Decreasing the concentration of carbon dioxide can be done by physical adsorption, which is the simplest method to immobilize of biomolecules such as $\mathrm{CO}_{2}$ which are bounded to the surface through weak bonds such as van der Waals forces [9]. There are three types of adsorbents, including elements that contain carbon (activated carbon and graphite), polymer elements (porous polymer matrix), and elements that contain oxides (silica gel and zeolites) [10].

XRF testing is carried out to find out the elements that exist in a material such as clay by bombarding the material with high energy $\mathrm{X}$-rays or gamma rays so that the waveforms of the clay-forming elements are detected.
[11]. Red brick is one of the ceramic products made from clay whose particles are shaped like a sheet that has a special surface with $\mathrm{Al}_{2} \mathrm{O}_{3}$ and $\mathrm{SiO}_{2}$ content in it [12]. Clay has high adsorption ability, it has very strong compressive power, it wrinkes when dried, and it has fine-grained granules so that it can be categorized as montmorillonite [13]. A mixture of tile powder and zeolite can reduce $\mathrm{CO}_{2}$ concentrations by $34.56 \%$ [14].

\section{RESEARCH METHODS}

Red brick powder, which came from the village of Urek - Urek Gondanglegi, Malang, Indonesian. The red brick adsorbent had fine structure, with particle sizez between 0.0625-0.4 mm. Each adsorbtion tube was filled with 200 and $400 \mathrm{~g}$ of adsorbent. Tests were conducted at biogas flow rates of 1 and $2 \mathrm{Lmin}^{-1}$ and purification times of 5 and $20 \mathrm{~min}$. Biogas is the gaseous result of digesting the chicken and cow manure in anaerobic conditions.

The composition of the red brick content based on XRF test consisted of $55.2 \% \mathrm{SiO}_{2}, 17.1 \% \mathrm{Al}_{2} \mathrm{O}_{3}, 13.1 \% \mathrm{CaO}$, $4.2 \% \mathrm{MnO}, 3.2 \% \mathrm{Na}_{2} \mathrm{O}, 3.14 \% \mathrm{TiO}_{2}$, and $2.4 \% \mathrm{BaO}$.

The following parameters were followed : $\mathrm{M}$ - adsorbent mass $(\mathrm{g}), \mathrm{Q}$ - biogas flow rate $\left(\mathrm{Lmin}^{-1}\right)$ and $\mathrm{t}$ - purification time ( $\mathrm{min}$ ). The equipment used in this research are Gas Chromatography (GC) at Greenhouse Gas Laboratory (Balingtan, Pati, Center Java), rotap rocker as a sieve to adjust grain size, digital balance to measure the mass of adsorbent, tedlar bag to accommodate post-purification gas samples, flowmeter to regulate flow rate, stopwatch to measure purification time, polyurethane hose for biogas distribution lines, distribution tubes for storing pressurized biogas, purifying equipment and biogas compression for transferring biogas from digesters 
to distribution tubes. The percentage of $\mathrm{CO}_{2}$ and $\mathrm{CH}_{4}$ concentration per treatment after purification and the effectiveness of adsorption for each treatment.

Tools and materials were prepared according to Figure 1. Biogas flows through tubes (no. 6 and 7 ) which have been filled with adsorbents into the sample bag.

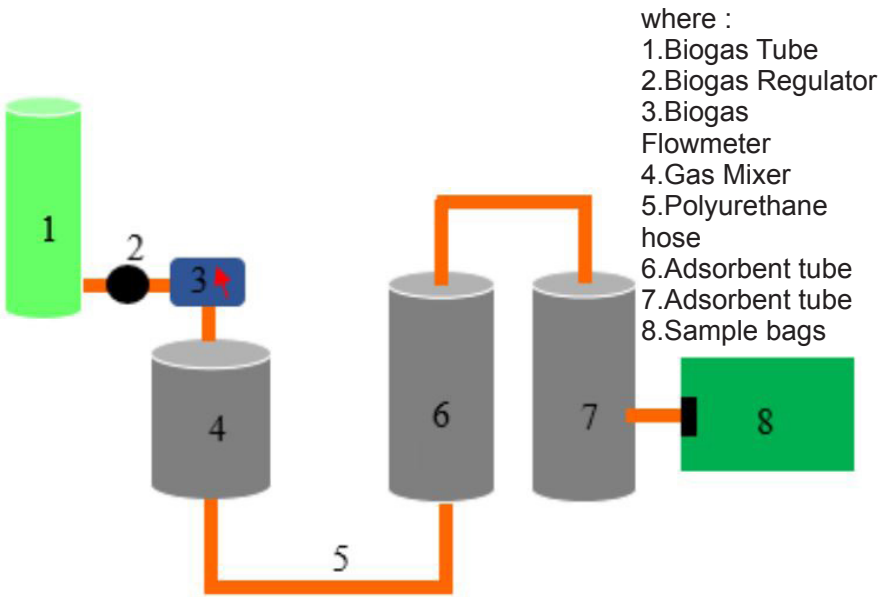

Figure 1: The scheme biogas purification equipment

Sampling done at time variations of 5 and 20 minutes, the sample bag was fully loaded (2 liters). Two repetitions were made for each variation. After the data obtained, an analysis was carried out using factorial design method $2^{3}$ to determine the effect of each treatment and the interaction between treatments on the binding of $\mathrm{CO}_{2}$ to biogas purification.

\section{RESULTS AND DISCUSSION $\mathrm{CO}_{2}$ CONCENTRATION}

The percentage data of the results of $\mathrm{CO}_{2}$ binding using red brick powder adsorbents obtained from Gas Chromatography (GC) are shown in Table 1.

Based on the data in Table 1 obtained a combination of factorial design data $2^{3}$ as shown in Figure 2.

The use of factorial design $2^{3}$ was carried out to determine the effect response of each adsorbent mass factor $(M)$, flow rate $(Q)$ and purification time (t) to the percentage $\mathrm{CO}_{2}$ produced by biogas. High level $(+)$ show high treatment value an low level (-1) shows low treatment value on each factor [15][16]. The matrix from in Figure 3 was obtained:
Table 1: $2^{3}$ factorial design scheme and $\% \mathrm{CO}_{2}$ after biogas purification

\begin{tabular}{|c|c|c|c|c|c|c|c|c|}
\hline \multicolumn{3}{|c|}{ Coding } & M & Q & $\begin{array}{c}t \\
(\min )\end{array}$ & $(\%)$ & $(\%)$ & $\overline{\mathrm{y}}(\%) \mathrm{CO}_{2}$ \\
\hline - & - & - & 200 & 1 & 5 & 17.25 & 17.13 & $17.189(1)$ \\
\hline+ & - & - & 400 & 1 & 5 & 10.32 & 11.84 & $11.082 \mathrm{a}$ \\
\hline - & + & - & 200 & 2 & 5 & 20.44 & 21.84 & $21.141 \mathrm{c}$ \\
\hline+ & + & - & 400 & 2 & 5 & 12.67 & 10.18 & $11.422 \mathrm{ac}$ \\
\hline - & - & + & 200 & 1 & 20 & 17.18 & 17.13 & $17.154 b$ \\
\hline+ & - & + & 400 & 1 & 20 & 10.33 & 10.31 & $10.319 a b$ \\
\hline - & + & + & 200 & 2 & 20 & 20.84 & 20.16 & $20.497 b c$ \\
\hline+ & + & + & 400 & 2 & 20 & 10.28 & 11.73 & $11 \mathrm{abc}$ \\
\hline \multicolumn{6}{|c|}{ Without treatment } & \multicolumn{3}{|c|}{25.34} \\
\hline
\end{tabular}

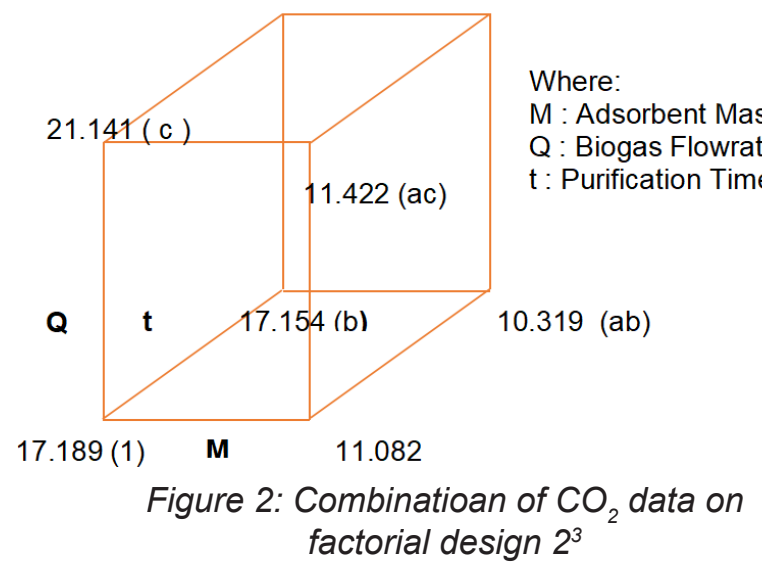

With the Gauss Siedel iteration method, the completion of matrix on Figure 3 is obtained:

$$
\begin{aligned}
y= & 14.976-4.0198 M+1.039 Q-0.233 . t-0.784 . M Q- \\
& -0.063 . M T-0.0335 . Q t+0.119 . M Q t
\end{aligned}
$$

Where:

$\mathrm{y}$ : The percentage of $\mathrm{CO}_{2}$ after biogas purification (\%)

IM: The Mass Factor of Brick Powder Adsorbent ( $g$ )

IQ: The Biogas Flowrate Factor $\left(\mathrm{L} \mathrm{min}^{-1}\right)$

It: The Purification Time Factor ( $\mathrm{min})$

$$
\left[\begin{array}{cccccccc}
1 & -1 & -1 & -1 & 1 & 1 & 1 & -1 \\
1 & 1 & -1 & -1 & -1 & -1 & 1 & 1 \\
1 & -1 & 1 & -1 & -1 & 1 & -1 & 1 \\
1 & 1 & 1 & -1 & 1 & -1 & -1 & -1 \\
1 & -1 & -1 & 1 & 1 & -1 & -1 & 1 \\
1 & 1 & -1 & 1 & -1 & 1 & -1 & -1 \\
1 & -1 & 1 & 1 & -1 & -1 & 1 & -1 \\
1 & 1 & 1 & 1 & 1 & 1 & 1 & 1
\end{array}\right]\left[\begin{array}{c}
\text { I0 } \\
\text { IM } \\
\text { IQ } \\
\text { It } \\
\text { IMQ } \\
\text { IMt } \\
\text { IQt } \\
\text { IMQt }
\end{array}\right]=\left[\begin{array}{c}
17.189 \\
11.082 \\
21.141 \\
11.422 \\
17.154 \\
10.319 \\
20.497 \\
11
\end{array}\right]
$$

Figure 3: Factorial Design $2^{3} \mathrm{CO}_{2}$ Data Matrix 
IMQ: The Interaction between Adsorbent Mass and Biogas Flowrate

IMt: The Interaction between Adsorbent Mass and Purification time

IQt: The Interaction between Biogas Flowrate and Purification time

IMQt: The Interaction between Adsorbent Mass, Biogas Flowrate, and Purification Time

Equation (1) explains that the greatest effect $(\geq \pm 0.5)$ occurs on the mass factor of adsorbent red brick powder, biogas flow rate, and mass interaction - flow rate on $\mathrm{CO}_{2}$ levels. A negative value on the $\mathrm{M}$ coefficient means that there is an effect of increasing mass on $\mathrm{CO}_{2}$ levels, $\mathrm{CO}_{2}$ concentration on 200 grams of the adsorbent mass is higher than 400 grams of the adsorbent mass, which means that the use of the adsorbent mass is more effective with higher levels. Likewise, mass - flow rate interactions have an effect on decreasing $\mathrm{CO}_{2}$ levels after purification even in small amounts. However, a positive value on the flow rate coefficient indicates that increas- ing the flow rate does not increase the binding of $\mathrm{CO}_{2}$ so that the flow rate of $1 \mathrm{Lmin}^{-1}$ is better for binding carbon dioxide compared to $2 \mathrm{Lmin}^{-1}$. This will be proven in the analysis of each treatment variable.

Analysis of the effect of the adsorbent mass on $\mathrm{CO}_{2}$ concentration in biogas with variable flow rates and time constant be seen in Figure 4.

Figure 4 shows that a mass of 200 grams has a higher $\mathrm{CO}_{2}$ concentration than a mass of 400 grams. The increase in the mass of the adsorbent will reduce the value of $\mathrm{CO}_{2}$ concentrations as a result of biogas purification. Increasing the mass of the adsorbent means that the volume also increases which will increase the area of the adsorbent. This will result in the increase of the contact area between the $\mathrm{CO}_{2}$ gas and the adsorbent, so the $\mathrm{CO}_{2}$ content will continue to decrease along with the increase in the mass of the adsorbent. These results are in line with previous studies [17], [18], [19], [20].

Analysis of the biogas flowrates effect on $\mathrm{CO}_{2}$ concentrations in biogas with mass and time variables can be seen in Figure 5.

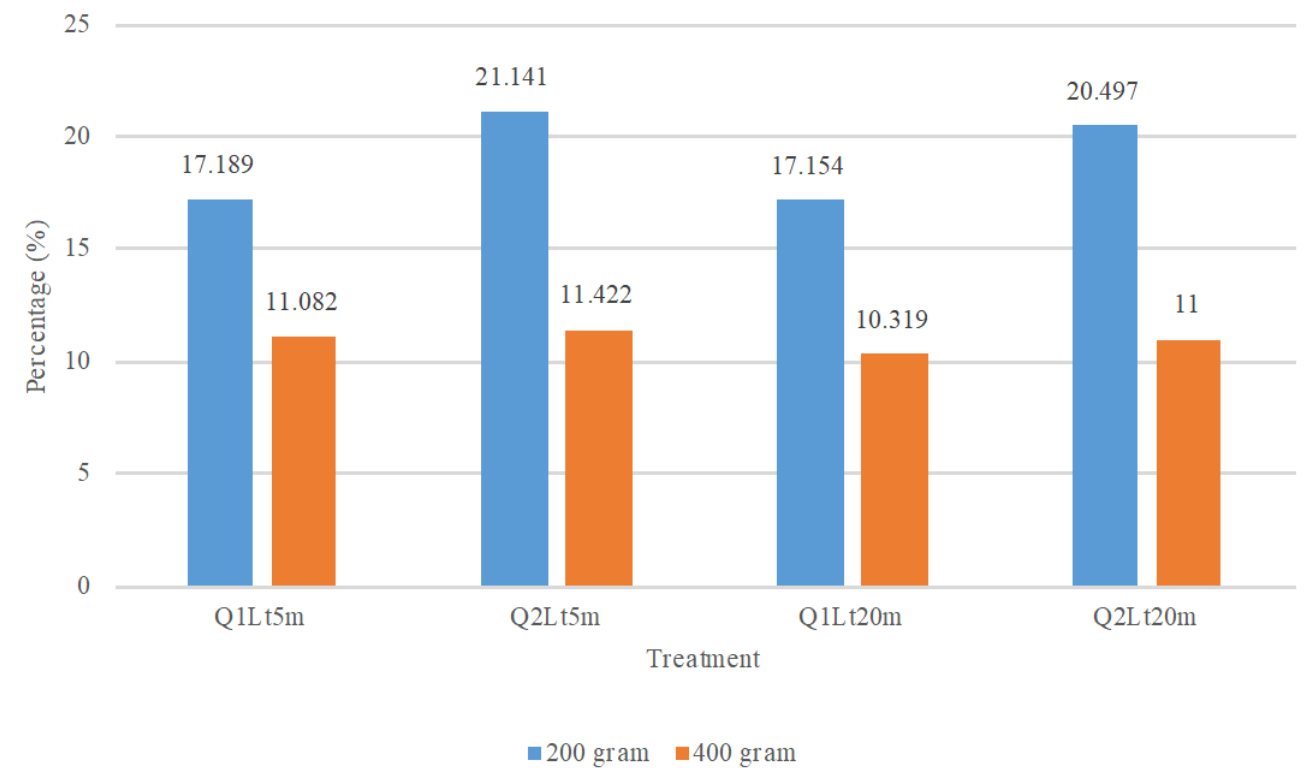

Figure 4: Adsorbent mass effect on $\mathrm{CO}_{2}$ concentrations

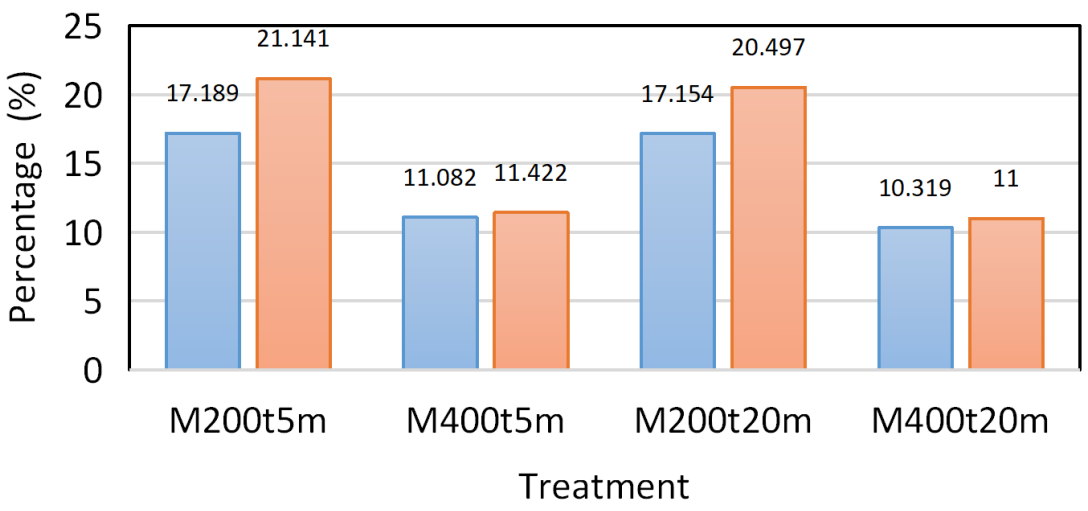

1 (Lmin-1) $\square 2$ (Lmin-1)

Figure 5: The diagram of biogas flowrates effect on $\mathrm{CO}_{2}$ concentrations 
Figure 5 shows that the flow rate of $2 \mathrm{Lmin}^{-1}$ has a higher $\mathrm{CO}_{2}$ concentration than the flow rate of $1 \mathrm{Lmin}^{-1}$. These results are in accordance with previous studies [21], [22] that high flow rates can cause a lot of biogas to be wasted because it was not adsorbed beforehand. Significant differences in $\mathrm{CO}_{2}$ concentrations between the flow rates 1 and 2 Lmin $^{-1}$ occur at a mass of 200 grams with a delta of around $3 \%$. This happens because the adsorbent is in small amount but the flow rate is too fast so that a lot of biogas is wasted without being bounded into the pores of the adsorbent.

The calculation of the efficiency of $\mathrm{CO}_{2}$ binding is done to find out the best treatment, using the formula [23]:

$\eta=\left(1-\frac{\mathrm{CO}_{2} \text { out }}{\mathrm{CO}_{2} \text { in }}\right) \times 100 \%$

where:

$\eta$ : The Efficiency of $\mathrm{CO}_{2}$ Adsorption (\%) $\mathrm{CO}_{2, \text { out }}$ : The $\mathrm{CO}_{2}$ Concentration After Purification (\%) $\mathrm{CO}_{2, \text { in }}$ : The $\mathrm{CO}_{2}$ Concentration Before Purification (\%)

The results of calculating the effectivity of $\mathrm{CO}_{2}$ adsorption are shown in Figure 6.

Figure 6, the highest effectivity occurred in the M400Q1Lt20m treatment at 59.28\%. The lower the concentration of $\mathrm{CO}_{2}$ after purification, the value of the effectivity of $\mathrm{CO}_{2}$ increases [14], [24]. It happens because the interaction of the variables makes the contact area larger between the red brick powder adsorbent and $\mathrm{CO}_{2}$ for the 400 gram mass variable, the binding of $\mathrm{CO}_{2}$ with the red brick powder adsorbent is more evenly distributed and minimal biogas is wasted for variable flow rates of $1 \mathrm{Lmin}^{-1}$, and the binding of $\mathrm{CO}_{2}$ is more maximal and evenly distributed before the saturated red brick adsorbent allows no biogas to be wasted for a 20 minute purification time variable. The interaction of these three variables makes the effectivity of the $\mathrm{CO}_{2}$ adsorption with adsorbent red brick powder to be high.

\section{$\mathrm{CH}_{4}$ CONCENTRATION}

Percentage data of post-purification $\mathrm{CH}_{4}$ results using red brick powder adsorbents obtained from Gas Chromatography as shown in Table 2
Data from Table 2 is converted to a combination of data models as shown in Figure 7.

Table 2: $2^{3}$ factorial design scheme and $\% \mathrm{CH}_{4}$ after biogas purification

\begin{tabular}{|c|c|c|c|c|c|c|c|}
\hline \multicolumn{2}{|c|}{ Coding } & \multirow[b]{2}{*}{200} & \multirow{2}{*}{$\begin{array}{c}\begin{array}{c}\mathrm{Q} \\
\left(\mathrm{L} \mathrm{min}^{-1}\right)\end{array} \\
1 \\
\end{array}$} & \multirow{2}{*}{$\begin{array}{c}\begin{array}{c}\mathrm{t} \\
(\mathrm{min})\end{array} \\
5 \\
\end{array}$} & \multirow{2}{*}{$\begin{array}{c}(\%) \\
\mathrm{CH}_{4} \\
47.53 \\
\end{array}$} & \multirow{2}{*}{\begin{tabular}{|c|}
$(\%)$ \\
$\mathrm{CH}_{4}$ \\
48.35 \\
\end{tabular}} & \multirow{2}{*}{$\frac{(\%) \bar{x}}{47.936(1)}$} \\
\hline- & - & & & & & & \\
\hline+ & -- & $\begin{array}{l}-400 \\
\end{array}$ & 1 & 5 & 58.68 & 67.13 & $62.904 \mathrm{a}$ \\
\hline- & + & - 200 & 2 & 5 & 66.32 & 56.98 & $61.648 \mathrm{c}$ \\
\hline+ & + & $\begin{array}{l}-400 \\
\end{array}$ & 2 & 5 & 66.44 & 65.00 & $68.402 \mathrm{ac}$ \\
\hline- & + & +200 & 1 & 20 & 69.09 & 45.10 & $57.096 \mathrm{~b}$ \\
\hline+ & + & $\begin{array}{r}+400 \\
\end{array}$ & 1 & 20 & 67.42 & 66.44 & $66.929 \mathrm{ab}$ \\
\hline- & ++ & $\begin{array}{l}+200 \\
\end{array}$ & 2 & 20 & 47.33 & 59.10 & $53.213 \mathrm{bc}$ \\
\hline+ & ++ & $\begin{array}{l}+ \\
+\end{array}$ & 2 & 20 & 69.04 & 67.76 & $\begin{array}{c}65.717 \\
\text { abc }\end{array}$ \\
\hline \multicolumn{5}{|c|}{ Without treatmer } & \multicolumn{3}{|c|}{36.8} \\
\hline
\end{tabular}

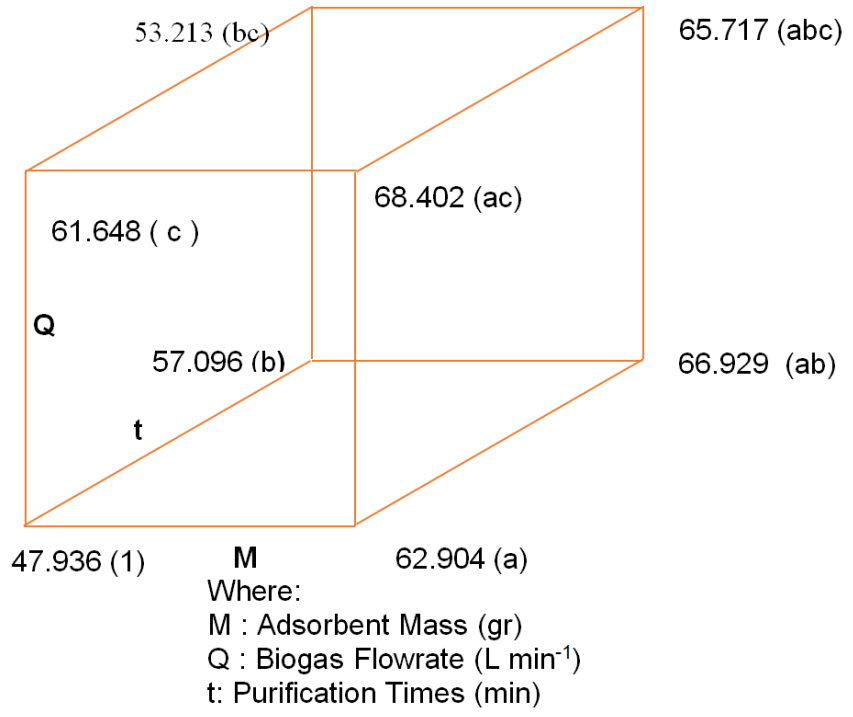

Figure 7: Combination of $\mathrm{CH}_{4}$ Data on Factorial Design $2^{3}$

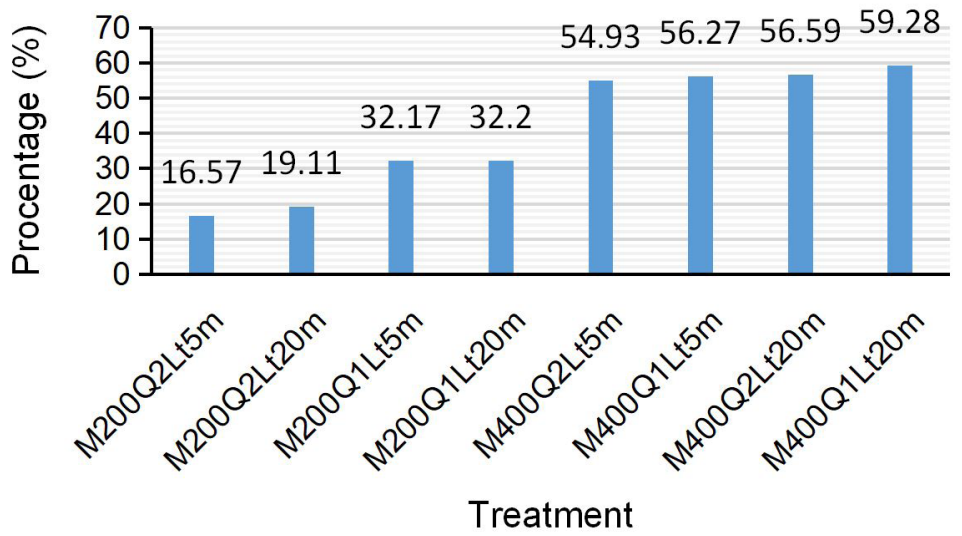

Figure 6: The Effectivity of $\mathrm{CO}_{2}$ Adsorption 
The use of factorial design $2^{3}$ was carried out to determine the effect response of each adsorbent Mass (M), Flowrate (Q) and Purification Time (t) to the $\% \mathrm{CH}_{4}$ of biogas purification. High level (+1) shows high treatment value and low level $(-1)$ shows low treatment value on each factor [15]. The matrix form is obtained in Figure 8; Method of the Gauss Siedel iteration was used the completion of matrix on Figure 8 is obtained:

$$
\left[\begin{array}{cccccccc}
1 & -1 & -1 & -1 & 1 & 1 & 1 & -1 \\
1 & 1 & -1 & -1 & -1 & -1 & 1 & 1 \\
1 & -1 & 1 & -1 & -1 & 1 & -1 & 1 \\
1 & 1 & 1 & -1 & 1 & -1 & -1 & -1 \\
1 & -1 & -1 & 1 & 1 & -1 & -1 & 1 \\
1 & 1 & -1 & 1 & -1 & 1 & -1 & -1 \\
1 & -1 & 1 & 1 & -1 & -1 & 1 & -1 \\
1 & 1 & 1 & 1 & 1 & 1 & 1 & 1
\end{array}\right]\left[\begin{array}{c}
F 0 \\
F M \\
F Q \\
F t \\
F M Q \\
F M t \\
F Q t \\
F M Q t
\end{array}\right]=\left[\begin{array}{l}
47.936 \\
62.904 \\
61.648 \\
68.402 \\
57.096 \\
66.929 \\
53.213 \\
65.717
\end{array}\right]
$$

Figure 8: Factorial Design $2^{3} \mathrm{CH}_{4}$ Data Matrix

where:

$x$ : The percentage of $\mathrm{CH}_{4}$ after biogas purification (\%)

FM: The Mass Factor of Brick Powder Adsorbent (g)

$\mathrm{FQ}$ : The Biogas Flowrate Factor $\left(\mathrm{L} \mathrm{min}{ }^{-1}\right)$

Ft: The Purification Time Factor (min)

FMQ: The Interaction between Adsorbent Mass and Biogas Flowrate

FMt: The Interaction between Adsorbent Mass and Purification time

FQt: The Interaction between Biogas Flowrate and Purification time

FMQt: The Interaction between Adsorbent Mass, Biogas Flowrate, and Purification time

Equation (3) explains that the greatest effect $(\geq 0.5)$ occurs in the mass factor of the adsorbent red brick powder, biogas Flowrate, Mass interaction - Flowrate, Flowrate - Purification Time Interaction, and Mass - Flow rate - Purification Time Influence $\mathrm{CH}_{4}$ levels. A positive value on the $\mathrm{M}$ coefficient means that there is an effect of increasing Mass on $\mathrm{CH}_{4}$ levels [17], [19], [20]. Increasing the mass of the adsorbent will increase the percentage of $\mathrm{CH}_{4}$ because a lot of $\mathrm{CO}_{2}$ is bound to the adsorbent, thereby increasing the ratio between $\mathrm{CH}_{4}$ and $\mathrm{CO}_{2}$.

The $Q$ value is positive, which means an increase in flow rate, increases the concentration of $\mathrm{CH}_{4}$ after purification [25], [26]. This is because the addition of the flow rate to the red brick adsorbent containing a lot of silica-alumina will trap or bind $\mathrm{CO}_{2}$ to the pores of the adsorbent due to van der Waals force and also the size of $\mathrm{CO}_{2}$ which is larger than $\mathrm{CH}_{4}$, at that time also smaller $\mathrm{CH}_{4}$ will pass through the adsorbent without being bound by the adsorbent, so the faster the biogas flow rate, the more $\mathrm{CH}_{4}$ levels are obtained.

The Mass Interaction Factor and the Flowrate (MQ) is negative, which means that there is an influence of interaction between variables on the decrease in $\mathrm{CH}_{4}$ although it is relatively small. This happens because the
Mass interaction and Flowrate are inversely proportional. Increased Mass will potentially increase $\mathrm{CH}_{4}$ levels because $\mathrm{CO}_{2}$ levels become reduced [17], [21], [22]. While an increase in Flowrate has the potential to reduce the ratio between $\mathrm{CO}_{2}$ and $\mathrm{CH}_{4}$ because although a lot of $\mathrm{CH}_{4}$ is obtained, there is also a lot of $\mathrm{CO}_{2}$ that has not been adsorbed so that the ratio decreases. [21], [22].

The interaction factor of Flowrate and Purification Time (Qt) is negative, which means there is an influence of interaction between variables on the decrease in $\mathrm{CH}_{4}$, because an increase in Flowrate has the potential to reduce the ratio between $\mathrm{CO}_{2}$ and $\mathrm{CH}_{4}$ because although a lot of $\mathrm{CH}_{4}$ is obtained, there is also a lot of $\mathrm{CO}_{2}$ that has not been adsorbed so the ratio decreases [21], [22]. While an increase in purification time will make the $\mathrm{CO}_{2}$ adsorption increase to the optimum point, then decrease thereby reducing the ratio of $\mathrm{CO}_{2}$ and $\mathrm{CH}_{4}$ levels [19], [27].

The adsorbent Mass Interaction Factor, biogas Flowrate, and Purification Time (MQt) are positive, which means there is an influence of interaction between variables on the increase in $\mathrm{CH}_{4}$. This happens because each factor has its own influence, and the influence of Mass has the biggest role so that the interaction of MQt is positive so there is an increase in $\mathrm{CH}_{4}$ in biogas purification.

\section{CONCLUSION}

Conclusions in this research, as follows:

1. The Mass factor of red brick powder adsorbent has the most influence in the results of biogas purification.

2. Red brick powder as an adsorbent in the biogas purification process has an influence on reducing $\mathrm{CO}_{2}$ levels due to high $\mathrm{SiO}_{2}$ and $\mathrm{Al}_{2} \mathrm{O}_{3}$ content which makes red brick a good adsorbent because more $\mathrm{CO}_{2}$ is bounded due to van der Waals forces on the red brick surface.

3. Red brick that has a lot of $\mathrm{CO}_{2}$ adsorption increases the ratio of $\mathrm{CH}_{4}$ to $\mathrm{CO}_{2}$.

\section{ACKNOWLEDGMENTS}

This research was funded by Faculty of Engineering, Brawijaya University, Malang, Indonesia with a contract agreement number: 19/UN10.F07/PN/2020

\section{REFERENCES}

1. Aleman-Nava, G.S., Casiano, V.H., Cardenas-Chavez, D.L., Diaz-Chavez, R., Scarlat, N and Mahlknecht, J.(2014). Renewable Energy Research Progress in Mexico: A Review. Renewable and Sustainable Energy Reviews, vol.32,140-153, doi. org/10.1016/j.rser.2014.01.004

2. Hossain, M.S and Rahman, M.F.(2020). Hybrid Solar PV/Biomass Powered Energy Effecient Remote Cellular Base Stations. International Journal of Renewable Energy Research, vol. 10, no.1, 329-342 
3. Garlucci, I., Mutani, G and Martino, M.(2015). Assessment of Potential Energy Producible form Agricultural Biomass in Municipalities of the Novara Plain. 2015 International Conference on Renewable Energy Research and Applications (ICRERA),p.22-25, DOI:10.1109/ICRERA.2015.7418636

4. Ulusoy, $Y$ and Ulukardesler, A. H.(2017). Biogas Production Potentialof Olive-mill Wastes in Turkey. 2017 IEEE 6th International Conference on Renewable Energy Research and Applications,p.5-8, DOI:10.1109/ICRERA.2017.8191143

5. Maile, O.I., Muzenda, E and Tesfagiorgis, H.(2017). Chemical Absorption of Cabon Dioxide in Biogas Purification. International Conference on Sustainable Materials Processing and Manufacturing, SMPM 2017,p.639-646, creativecommons.org/licences/bync-nd/4.0.

6. Yentekakis, I.V and Goula, G.(2017). Biogas Management: Advanced Utilization for Production of Renewable Energy and Added-value Chemicals. Frontiers in Environmental Science vol.5 (article7), DOI:10.3389/fenvs.2017.00007

7. Maile, O. I., Tesfagiorgis, $\mathrm{H}$ and Muzenda, E.(2017). Possible Absorbent Regeneration in Biogas Purification and Upgrading : A Review. The Nexus: Energy. Environment and Climate Change, 273-287, DOI/10.1007/978-3-319-63612-2_17

8. Gerlach, F., Grieb, B and Zerger, U.(2013). Sustainable Biogas Production: A Handbook for Organic Farmers. FiBL Projekte $\mathrm{GmbH}$, Germany

9. Thiyam, P., Persson, C., Parsons, D.F., Huang, D., Buhmann, S.Y and Bostrom,M.(2015). Trends Of CO2 adsorption on celuluose due to can der Waals, Forces. Colloids and Surfaces A Phyisicochemical and Engineering Aspects, vol.470, no.1, 316-321, DOI:10.1016/j/consurfa.2014.12.044

10. Gawande, S.M., Belwalkar, N.S and Mane, A.A.(2017). Adsorption and its Isotherm - Theory. International Journal of Engineering Research, vol.6, no.6,312-316, DOl;10.5958/23196890.2017.00026.5

11. Ikegwu, J. U and Uzuegbu, J.(2015). X-ray Fluorescence Investigation of Clay Minerals for Pottery Making in Abakiliki Formation, Nigeria. Nyame Akuma, no.84,1-11

12. Rahman, N.A., Widiyastuti, W., Ajiza, M and Laksmana, D.(2020). Application of Amine Modified Silica Adsorbenes on CO2 Adsorption in Biogas. Proceedings of the 2nd International Conference on Quran and Hadith Studies Information Technology and Media in Conjuction with the 1st International Conference on Islam, Science and Technology, ICONQUHAS \& ICONIST (2018), Bandung, Indonesia, DOI:10.4108/eai.2-10-2018.2295556
13. Auta, M and Hameed, B.H.(2012). Modified Mesoporous Clay Adsorbent For Adsorption Isotherm And Kinetics Of Methylene Blue. Chemical Engineering Journal, vol.198-199, 219-227, DOI/10.1016/j. cej.2012.05.075

14. Chouikhi, N., Cecilia, J.A., Vilarrasa-Garcia, E., Besghaier, S., Chlendi, M., Duro, F.I.F., Castellon, E.R and Bagane, M.(2019). CO2 Adsorption of Materials Synthesized from Clay Minerals: A Review. Minerals, vol.9, no.514, 1-22, DOl:10.3390/min9090514

15. Lhanafi, S., Anfar, Z., Chebli, B., Benafqir, M., El-Haouti, R., Azougarh, Y., Abbaz, M and El-Alem, N.(2018). Factorial Experimental Design to Enhance Methane Production of Dairy Wastes Co-Digestion. Sustainable Environment Research, vol.28, no.6, 289-395, DOI: 10.1016/j.serj.2018.05.001

16. Rashid, M., Shakib, N and Rahman, T.(2019). Biogas Production from POME by Optimum Level of Inputs. Smart Grid and Renewable Energy, vol.10, no.8, 203-212, DOI : 10.4236/sgre.2019.108013

17. Wuri, M.A., Pertiwiningrum, A., Budiarto, R and Koranto, C.A.D.(2018). Characterization of Natural Zeolite and Chicken Manure Derived Biochar for Carbon Dioxide Adsorption in Biogas. E3S Web of Conferences, Astechnova2017, vol.43, no.4,1-4, DOI : $10.1051 / \mathrm{e} 3$ sconf/20184301008

18. Benefield, L.D.(1982). Process Chemistry For Water And Wastewater Treatment. Prentice Hall Inc., Engelwoods Cliffs, New York

19. Mrosso, R., Machunda, R and Pogrebnaya, T.(2020). Removal of Hydrogen Sulfide from Biogas Using Red Rock. Hindawi Journal of Energy,vol.2020,1-10 ,DOI:10.1155/2020/2309378

20. O.I. Maile, O.I., Tesfagiorgis, $H$ and Muzenda, E.(2017). The potency of monoethanolamine in biogaspurification and upgrading. South African Journal of Chemical Engineering, vol.24,122-127, DOI:10.1016/j.sajce.2017.06.004

21. Lety, T., Dina, E.K., Tahdid, T., Ridwan, K.A., Alfarizi, M.N and Mangihut, P.L.(2020). The Effect of flowrate and $\mathrm{NaOH}$ Concentration to $\mathrm{CO} 2$ Reduction in Biogas Products Using Absorber. IOP Journal Physic: Conferencies Series, vo.1500, DOI:10.1088/17426596/1500/1/012054

22. Ghatak, M.D and Mahanta, P.(2016). Biogas Purification using Chemical Absorption. International Journal of Engineering and Technology, vol. 8, no. 3, 1600-1605,

23. Mitzlaff, K.V.(1988). Engines for Biogas. A Publication of the Deutsches Zentrum für Entwicklungstechnologien GATE, a division of the 1988 Deutsche Gesellschaft fur Technische Zusammenarbeit (GTZ) $\mathrm{GmbH}$ 
24. Adnan, A.I., Ong, M.Y., Nomanbhay, S., Chew, K.W and Show, P.L.(2019). Technologies for Biogas Upgrading to Biomethane: A Review. Bioengineering, vol.6, no.92, 1-23, DOl:10.3390/bioengineering6040092

25. Saleh, A., Melwita, E., Prastyowati., Manulu, L.F and Christian, Y.(2014). Increasing Percentage of Methane $(\mathrm{CH} 4)$ from Biogas with Purification by Using Zeolite Membrane. Proceedings of The 5th Sriwijaya International Seminar on Energy and Environmental Science \& Technology, Palembang Indonesia 2014, p.97-101
26. Walozi, R., Nabuuma, B and Sebiti, A.(2016). Application of Low Pressure Water Scrubbing Technique for Increasing Methane Content in Biogas. Universal Journal of Agricultural Research, vol. 4, no.2, 60-65, DOI:10.13189/ujar.2016.040206

27. Tufaner, F and Avsar, Y.(2016). Effects Of Co-Substrate On Biogas Production From Cattle Manure: A Review. Int.ernational Journal Environmental Science and Technology, vol.13, no.9, 2303-2312, DOI:10.1007/s13762-016-1069-1 